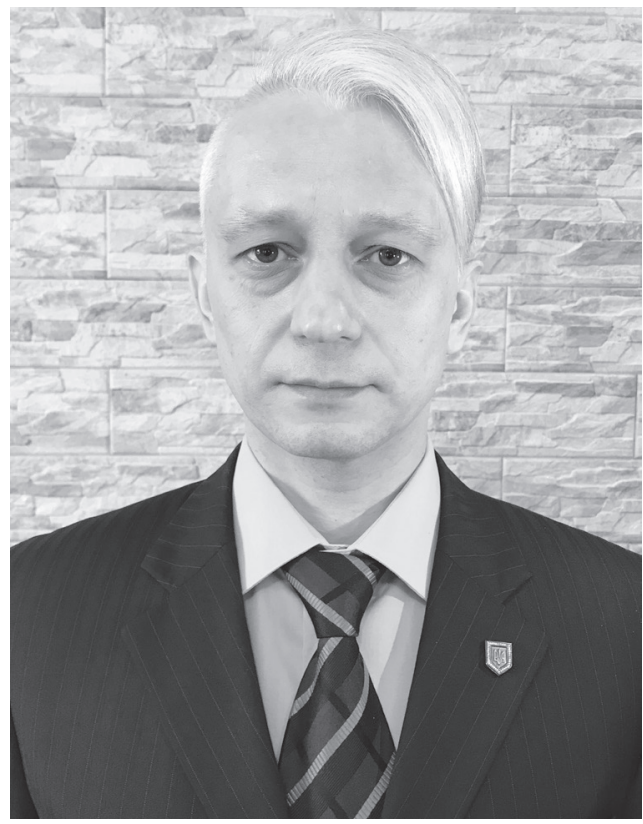

Shyrokov Serhii Borysovich,

Academy of Public Administration under the President of Ukraine, 49044, Dnipro, Gogol Str., 29, phone +38 (067) 745-43-43, e-mail: serg.shyrokov@gmail.com, https://orcid.org/00000003-0168-6756

\title{
МОТИВАЦІЯ У ПАТРІОТИЧНОМУ ВИХОВАННІ
}

Анотація. Висвітлено питання пошуку та обгрунтування нових підходів до мотивації у процесі національно-патріотичного виховання громадян задля подальшого успішного розвитку незалежної держави Україна.

Виклики останнього часу виявили проблеми у процесі національно-патріотичного виховання, які були накопичені за роки незалежності України, та зумовили необхідність його осучаснення. Новий погляд на національно-патріотичне виховання громадян повинен сприяти консолідації та розвитку суспільства, що вимагає постійного його вдосконалення.

Після Революції Гідності національно-патріотичне виховання набуває характеру системної і цілеспрямованої діяльності органів державної влади, органів місцевого самоврядування, закладів освіти, організацій громадянського суспільства, громадян з формування у людини і громадянина високої національно-патріотичної свідомості, почуття відданості своїй Українській державі. В основу системи національно-патріотичного виховання покладе- 
но ідеї зміцнення української державності як консолідуючого чинника розвитку суспільства, формування патріотизму та утвердження національних цінностей.

Як і в кожного управлінського процесу, успіх національно-патріотичного виховання залежить не в останню чергу від вдалих напрацювань у його складовій - мотивації. Основний програмний документ у формуванні державної політики національно-патріотичного виховання в Україні - Указ Президента України від 18 травня 2019 р. № 286/2019 “Про Стратегію національно-патріотичного виховання” містить напрями мотивації суб'єктів виховного процесу, але зовсім не містить напрямів мотивації суб'єктів вияву патріотичних почуттів, тобто об'єктів виховного процесу. Автор на підставі залучення історичного досвіду розвитку явища патріотизму пропонує додати нові елементи у виховні завдання національно-патріотичного виховання, як складової громадянської освіти, та до інформаційного забезпечення цього процесу. Додавання такого акценту дозволить підійти до формування необхідних якостей не з боку почуття обов'язку, а з боку взаємин, де реалізація прав і свобод людини можлива лише за умови лояльності та якомога більшої підтримки соціальних інститутів, через які вони реалізовуються, тобто через державу у широкому її розумінні.

Ключові слова: патріотизм, виховання, свідомість, мотивація.

\section{МОТИВАЦИЯ В ПАТРИОТИЧЕСКОМ ВОСПИТАНИИ}

Аннотация. Освещен вопрос поиска и обоснования новых подходов к мотивации в процессе национально-патриотического воспитания граждан для дальнейшего успешного развития независимого государства Украина.

Вызовы последнего времени выявили проблемы в процессе национально-патриотического воспитания, которые были накоплены за годы независимости Украины, и обусловили необходимость его обновления. Новый взгляд на национально-патриотическое воспитание граждан должен способствовать консолидации, развитию общества и требует постоянного совершенствования.

После Революции Достоинства национально-патриотическое воспитание приобретает характер системной и целенаправленной деятельности органов государственной власти, органов местного самоуправления, учебных заведений, организаций гражданского общества, граждан по формированию у человека и гражданина высокого национально-патриотического сознания, чувства верности своему Украинскому государству. В основу системы национально-патриотического воспитания положены идеи укрепления украинской государственности как консолидирующего фактора развития общества, формирования патриотизма и утверждения национальных ценностей.

Как и у каждого управленческого процесса, успех национально-патриотического воспитания зависит не в последнюю очередь от удачных наработок в его составной части - мотивации. Основной программный документ в формировании государственной политики национально-патриотическо- 
го воспитания в Украине - Указ Президента Украины от 18 мая 2019 г. № 286/2019 “О Стратегии национально-патриотического воспитания" содержит направления мотивации субъектов воспитательного процесса, но совсем не содержит направлений мотивации субъектов проявления патриотических чувств, то есть объектов воспитательного процесса. Автор на основании исторического опыта развития явления патриотизма предлагает добавить новые элементы в воспитательные задачи национально-патриотического воспитания, как составляющей части гражданского образования, и в информационное обеспечение этого процесса. Добавление такого акцента позволит подойти к формированию необходимых качеств не со стороны чувства долга, а со стороны взаимности, где реализация прав и свобод человека возможна только при условии лояльности и как можно большей поддержки социальных институтов, через которые они реализуются, то есть через государство в широком его понимании.

Ключевые слова: патриотизм, воспитание, сознание, мотивация.

\section{MOTIVATION IN PATRIOTIC EDUCATION}

Abstract. The article is devoted to the search and justification of new approaches to motivation in the process of national-patriotic education of citizens for the further successful development of the independent state of Ukraine.

Recent events have revealed problems in the process of national-patriotic education. These problems have been accumulated over the years of Ukraine's independence and necessitated the updating of this process. Modernization of national-patriotic education of citizens should contribute to the consolidation, development of society and requires constant improvement. After the Revolution of Dignity, national-patriotic education becomes a systematic and purposeful activity of state authorities, local authorities, educational institutions, civil society organizations, citizens for the formation of a person with a high national-patriotic consciousness, a sense of fidelity towards the Ukrainian state. The basis of the system of national-patriotic education is the idea of strengthening Ukrainian statehood as a consolidating factor in the development of society, the formation of patriotism and the establishment of national values.

Like every management process, the success of national-patriotic education depends not least on successful developments in its component part- motivation. The main program document in the formation of the state policy of nationalpatriotic education in Ukraine - Decree of the President of Ukraine dated May 18, 2019 № 286/2019 “On the Strategy of National-Patriotic Education” contains directions for motivation of subjects of the educational process, but does not contain directions for motivation of subjects of manifestation of patriotic feelings, that is, the objects of the educational process. Based on the historical experience of the development of the phenomenon of patriotism, the author suggests adding new elements to the tasks of national-patriotic education and to the information support of this process. Such an emphasis will allow us to approach the formation of the necessary qualities not on the part of a sense of duty, but on 
the side of reciprocity, where the realization of human rights and freedoms is possible subject to loyalty and as much as possible support for the social institutions through which they are realized, that is, through the state in its broad sense.

Keywords: patriotism, education, consciousness, motivation.

Постановка проблеми. Виклики останнього часу виявили проблеми у процесі національно-патріотичного виховання, які були накопичені за роки незалежності України, та зумовили необхідність його осучаснення. На тлі сучасних тенденцій панування "ratio" та нівелювання духовного постає проблема недостатньої мотивації об'єктів виховного процесу мати патріотичну свідомість та реалізовувати іï у патріотичних вчинках, тому пошук та обгрунтування нових підходів до такої складової державно-управлінського процесу як мотивація у національно-патріотичному вихованні є актуальним завданням сьогодення.

Аналіз останніх досліджень і публікацій. Проблематикою явища займалися такі дослідники як А. Миронов, О. Вишневський, Г. Ващенко, В. Кротюк, М. Потапова, И. Харламов, Е. Кондрашова, однак, з огляду на сучасні виклики питання мотивації носіїв патріотичної свідомості та суб'єктів патріотичних вчинків потребує модернізації.

Мета статті - пошук та обгрунтування нових підходів до мотивації у процесі національно-патріотичного вихованні задля його модернізації та відповідності сучасним викликам.

Виклад основного матеріалу. Основним програмним документом у формуванні державної політики на- ціонально-патріотичного виховання в Україні є Указ Президента України від 18 травня 2019 року № 286/2019 "Про Стратегію національно-патріотичного виховання" (надалі Стратегія) [1]. За мету в Указі визначені:

- подальший розвиток в суспільстві національної свідомості;

- формування почуття патріотизму на засадах духовності та моральності;

- популяризація духовно-культурної спадщини Українського народу;

- активізація взаємодії органів державної влади, органів місцевого самоврядування та громадських об'єднань у питаннях національно-патріотичного виховання.

Тобто Президентом України завданий певний напрям діяльності у сфері державного управління; їі суб'єктами визнані органи державної влади, органи місцевого самоврядування та громадські об'єднання; об'єктами - індивіди, в яких треба сформувати специфічні психологічні якості та знання, що мають знайти свій відбиток навіть у колективному несвідомому. У цьому напрямі діяльності поширення серед народних мас у загальнодоступній, дохідливій формі надбань Українського народу [2] є тривіальним та доволі просим завданням порівняно з формуванням якостей, які згідно Стратегії, мають бути: 
- повага до Конституції і законів України;

- соціальна активність та відповідальність за доручені державні та громадські справи;

- готовність до виконання обов'язку із захисту незалежності та територіальної цілісності України;

- формування у людини і громадянина почуття відданості своїй Українській державі, поваги до державної мови;

- усвідомлення досягнень Українського народу, його інтелектуальних, духовних та інших надбань;

- діяльнісна відданість розбудові України як суверенної держави, формування активної громадянської та державницької позиції, почуття власної та національної гідності;

- національно-культурна громадянська ідентичність;

- сповідування європейських цінностей,

- висока національно-патріотичної свідомість,

- почуття патріотизму.

3 погляду суб'єкт-об'єктних відносин державне управління $є$ неперервним процесом реалізації відповідних управлінських функцій, у зв'язку з чим для нього можна застосувати визначення через ці функції, а саме: державне управління $є$ процесом планування, організації, мотивації, контролю та пов'язуючих ïx функцій комунікації і прийняття рішень з метою формулювання та досягнення цілей держави. Уточнюючи та доповнюючи це визначення, до предмета державне управління слід віднести процеси здійснення суб'єктом державного управління функцій управління (планування, організації, мотивації, контролю, комунікації, прийняття рішень) з метою досягнення цілей держави шляхом формування організуючого, координуючого та контролюючого впливів на об'єкт державного управління [3].

Зосередимося більш детально на такому складовому процесі державного управління як мотивація. Стосовно мотивації суб'єктів виховного процесу патріотичного виховання зі сторони органів державної влади та органів місцевого самоврядування Стратегія зокрема у розділі 6 містить наступні пункти про те, що ефективна її реалізація потребує:

- механізмів підтримки об'єднань, центрів, клубів, діяльність яких пов'язана 3 національно-патріотичним вихованням, закладів освіти, культури та мистецтв, а також їхніх працівників;

- розроблення системи заохочення громадських об'єднань та активістів, закладів освіти та педагогічних працівників за плідну діяльність у сфері національно-патріотичного виховання, яка відповідає ціннісним орієнтирам та індикаторам ефективності Стратегії. Однак, на думку автора, не приділено достатньо уваги мотивації об'єктів виховного процесу патріотичного виховання, тобто мотивації суб'єктів патріотичних почуттів та вчинків до формування у себе якостей перелічених у Стратегії та їх проявів.

3 іншого боку, з точки зору процесу виховання, будемо мати аналогічні питання щодо мотивації. 3 утворенням перших найдавніших людських спільнот (сім'ї, племені, общини) перед ними поставала потреба передавати свої досвід і знання наступним 
поколінням, у певний спосіб впливати на їх поведінку, що загалом мало сприяти виживанню людського роду, формувати моральні, психологічні, фізичні якості нащадків. Отже, проблема наставництва, навчання, виховання виникла одночасно 3 появою людського соціуму. 3 розвитком цивілізації виховання підростаючих поколінь ставало все більш осмисленим, набувало досконаліших форм і методів [4]. Зараз, на думку автора, у інформаційному суспільстві, в епоху “пост-правди” та нівелювання духовного ще більш нагальною стає потреба у підвищених вимогах до мотивації об'єкту виховного процесу набувати певних потрібних якостей.

У педагогіці процес виховання поділяють на чотири етапи. Перший етап - усвідомлення норм і правил поведінки; другий - формування ставлення до цих норм та правил; третій - формування поглядів та переконань (сприйняття, засвоєння i перетворення засвоєних норм в особисте надбання); четвертий - через багаторазове повторення формування навичок та звичок поведінки, яка відповідає особистим переконанням та переходить до рис характеру [4]. Видатні педагоги А. С. Макаренко та В. О. Сухомлинський практикували проведення спеціальних бесід теоретичного роз'яснювального характеру про необхідність вести себе певним чином. Зараз за тотальним пануванням "ratio" задля спонукання до дій замало роз'яснень, що такі дії потрібно робити чи розповідей про приклади, що хтось їх робить або робив. Саме мотивація скорочує шлях від зрозумілих та засвоєних абстрактних понять до конкретних дій в їх реалізацію.

На думку автора, патріотизм має свої витоки та першооснову у прагненні кожної живої істоти до відтворення, яке нерозривно пов'язано з боротьбою за виживання своє та свого потомства, з захистом та розширенням створеного життєвого середовища. Історичний досвід розвитку явища патріотизму вказує на те, що об'єкти патріотизму завжди були саме тим середовищем, яке й забезпечувало перш за все це відтворення. Домінування того чи іншого об'єкту патріотизму на протязі історичного процесу пов'язано лише з розвитком людства у суспільному та індивідуальному вимірах. Домінуючим завжди був той об’єкт, який на цьому проміжку часу був найбільш критичним для задоволення життєвих потреб, у граничному вимірі - задля виживання, для більшості населення певної території, тому кочівник відчуває патріотичні почуття до свого роду-племені, землероб до рідної землі, городянин-ремісник до городу де він обмінює всій товар. Так само йдуть справи й з іншими об'єктами, такими як батьківщина, нація та держава. Також природно у суб'єкта виникає потреба служіння об'єкту та потреба в його захисті [5].

Для інтенсифікації процесу патріотичного виховання та отримання більш вагомих його результатів доречно поглибити використання історичного досвіду розвитку явища патріотизму та поєднання його 3 “усвідомленням взаємозв’язку між індивідуальною свободою, правами людини та їi патріотичною відповідальністю” як 3 одним із виховних 
завдань, через систему яких конкретизується мета національно-патріотичного виховання Концепції національно-патріотичного виховання дітей і молоді [6].

Так, вибірковий аналіз програм національно-патріотичного виховання, розміщених на офіційних сайтах органів державної влади, органів місцевого самоврядування, закладів освіти, виявив, що вони містять тільки інструменти сформування специфічних психологічних якостей та знань особистостей у соціумі, які, безперечно, мають дати результат, але не містять інструментів формування відповіді на питання в уяві об'єктів виховання про те, навіщо їм формувати в себе такі якості та проявляти їх в діях, тобто не містять мотивації суб'єктів патріотичних почуттів їх мати та проявляти. На думку автора, ця відповідь для об'єктів виховання не є очевидною, та вона може не сформуватися сама по собі, а вдале іiі формування забезпечить свій позитивний внесок у загальний результат національно-патріотичного виховання.

Основними складовими національно-патріотичного виховання згідно Стратегії є: громадсько-патріотичне, військово-патріотичне та духовно-моральне виховання [1]. 3 іншого боку, згідно Концепції розвитку громадянської освіти в Україні, національно-патріотичне виховання $\mathrm{E}$ складовою системи громадянської освіти [6]. Основними стратегічними напрямами громадянської освіти є:

- правова освіта громадян, зокрема в частині розуміння та вміння реалізовувати власні конституційні права та обов’язки;
- посилення здатності брати участь у суспільному житті та використовувати можливості впливу на процеси прийняття рішень на всеукраїнському та місцевому рівні (реалізація права на участь) [6].

3 іншого боку, сучасна держава - соціальний арбітр, орган керівництва загальними справами, організатор багатьох важливих заходів, без здійснення яких неможливе функціонування суспільства. Важливе місце у цьому процесі належить закріпленню, забезпеченню прав i свобод людини, екологічній безпеці, технічному прогресу, здоров'ю нації, безконфліктному існуванню суспільства, забезпеченню гідного прожиткового рівня, підтримання науки, культури, освіти. Держава покликана перешкоджати різкій диференціації суспільства з метою уникнення гострих соціальних конфліктів [3]. Тобто саме держава і є тим соціальним інститутом, через який реалізуються конституційні права, та який дає можливість впливу на процеси прийняття рішень на всеукраїнському та місцевому рівні. А якщо це так, то за допомогою відповідної педагогічної роботи у об'єкта виховного процесу не складно сформувати переконання про необхідність патріотичної відповідальності, зауважимо, не $з$ точки зору обов'язків, а з точки зору необхідності захисту того середовища, через яке він має змогу реалізувати свої права, тобто реалізувати свої потреби у розумінні історичного розвитку явища патріотизму [5]. Додавання такого акценту дозволить підійти до формування необхідних якостей не з боку почуття обов'язку, а боку взаємин, де реалізація прав 
і свобод людини можлива лише за умови лояльності та якомога більшої підтримки соціальних інститутів, через які вони реалізовуються, тобто через державу у широкому іiі розумінні. Застосування такого підходу, на думку автора, покращить загальні результати процесу національно-патріотичного виховання.

Висновки. Основними складовими національно-патріотичного виховання є: громадсько-патріотичне, військово-патріотичне та духовно-моральне виховання. Реалізація державної політики національно-патріотичного виховання $€$ державно-управлінським процесом, в якому як й в будь-якому управлінському процесі його функція мотивації має важливе значення. Національно-патріотичне виховання є важливим засобом громадянської освіти в Україні та є її складовою. Основними стратегічними напрямами громадянської освіти є:

- правова освіта громадян, зокрема в частині розуміння та вміння реалізовувати власні конституційні права та обов'язки;

- посилення здатності брати участь у суспільному житті та використовувати можливості впливу на процеси прийняття рішень на всеукраїнському та місцевому рівні (реалізація права на участь).

Одним з виховних завдань національно-патріотичного виховання $€$ усвідомлення об'єктами виховання (суб'єктами патріотичних почуттів та вчинків) взаємозв'язку між індивідуальною свободою, правами людини та її патріотичною відповідальністю. Держава, у широкому розумінні, $є$ саме тим інститутом, який забезпе- чує реалізацію конституційних прав, тому патріотичну відповідальність й слід розглядати не тільки як обов'язок для об'єктів виховного процесу, а й як мотивуючий фактор для забезпечення реалізації прав і свобод людини у частині лояльності та захисту інституту який таку реалізацію забезпечує. Саме такий кут зору на це виховне завдання національно-патріотичного виховання слід додати до його інформаційного забезпечення, й саме такий кут зору буде вагомим внеском у досягнення мети всього процесу. Крім того, такий погляд цілком відповідає сучасному баченню оновлення процесів публічного управління та адміністрування у частині залучення до них елементів стимулювання та мотивації з управління бізнес процесами.

Перспективи подальших досліджень. Перспективи подальших досліджень вбачаються в пошуках межи перетинання реалізації прав i свобод людини з визначенням пріоритетів, які притаманні будь-яким проявам явища патріотизму.

\section{СПИСОК ВИКОРИСТАНИХ ДЖЕРЕЛ}

1. Указ Президента України від 18 травня 2019 року № 286/2019 "Про Стратегію національно-патріотичного виховання" [Електронний ресурс]. Режим доступу: https://www.president.gov.ua/ documents/2862019-27025

2. Академічний тлумачний словник (1970-1980) [Електронний ресурс]. Режим доступу:http://sum.in.ua/s/ populjaryzacija

3. Енциклопедія державного управління : у 8 т. / Нац. акад. держ. упр. при Президентові України ; наук.-ред. 
колегія : Ю. В. Ковбасюк (голова) та ін. Київ : НАДУ, 2011. Т. 1 : Теорія державного управління / наук.-ред. колегія : В. М. Князєв (співголова), I. В. Розпутенко (співголова) та ін. $2011.748 \mathrm{c}$.

4. Волкова Н. П. Педагогіка: навч. посіб. 2-ге вид., переробл., допов. Київ: Академвидав. 2007.

5. Широков С. Джерела, витоки та першооснова явища патріотизму // Актуальні проблеми державного управління : зб. наук. пр. ОРІДУ/ [голов. ред. М.М. Іжа]. Вип. 3 (79). Одеса : ОРІДУ НАДУ, 2019. 112 с.

6. Розпорядження Кабінету міністрів України від 3 жовтня 2018 р. № 710-р "Про схвалення Концепції розвитку громадянської освіти в Україні" [Електронний ресурс]. Режим доступу: https://zakon.rada. gov.ua/laws/show/710-2018-\%D1\%8

\section{REFERENCES}

1. Ukaz Prezydenta Ukrainy "Pro Stratehiiu natsionalno-patriotychnoho vykhovannia" : vid 18 travnia 2019 roku, № 286/2019 [Decree of the President of Ukraine "On the Strategy of National-Patriotic Education" from May 18, 2019, № 286/2019]. (n.d.). wrw.president.gov.ua. Retrieved from https://www.president.gov. ua/documents/2862019-27025 [in Ukrainian].
2. Akademichnyi tlumachnyi slovnyk (1970-1980) [Academic Explanatory Dictionary (1970-1980)]. sum.in.ua. Retrieved from http://sum.in.ua/s/ populjaryzacija [in Ukrainian].

3. Kovbasiuk Yu. V., Kniaziev V. M., Rozputenko I. V., et al. (Eds.). (2011). Entsyklopediia derzhavnoho upravlinnia. T. 1: Teoriia derzhavnoho upravlinnia [Encyclopedia of Public Administration. Vol. 1: Theory of public administration]. Kyiv: NADU [in Ukrainian].

4. Volkova N. P. (2007). Pedahohika [Pedagogy]. (2 $2^{\text {nd }}$ ed., rew.). Kyiv: Akademvydav [in Ukrainian].

5. Shyrokov S. (2019). Dzherela, vytoky ta pershoosnova yavyshcha patriotyzmu [Sources, origins and the basis of the phenomenon of patriotism]. $A k$ tualni problemy derzhavnoho upravlinnia - Actual problems of public administration, 3(79), 26-29 [in Ukrainian].

6. Rozporiadzhennia Kabinetu ministriv Ukrainy "Pro skhvalennia Kontseptsii rozvytku hromadianskoi osvity v Ukraini" : vid 3 zhovtnia 2018 r., № 710-r [Order of the Cabinet of Ministers of Ukraine "On approval of the Concept of development of civic education in Ukraine" from October 3, 2018, № 710-r]. (n.d.). zakon.rada. gov.ua. Retrieved from https://zakon. rada.gov.ua/laws/show/710-2018$\%$ D1\%80 [in Ukrainian]. 